Jurnal Health Sains: p-ISSN: 2723-4339 e-ISSN: 2548-

1398 Vol. 2, No. 3, Maret 2021

\title{
GAMBARAN TINGKAT PENGETAHUAN SWAMEDIKASI OBAT ANALGESIK PADA MAHASISWA-MAHASISWI UNIVERSITAS TADULAKO DI KOTA PALU
}

\section{Rini Irawati, Amelia Rumi dan Firdawati Amir Parumpu}

Universitas Tadulako Palu Sulawesi Tengah, Indonesia

Email: riniaskaar@gmail.com, amelia.rumi@gmail.com dan firdaamirparumpu@gmail.com

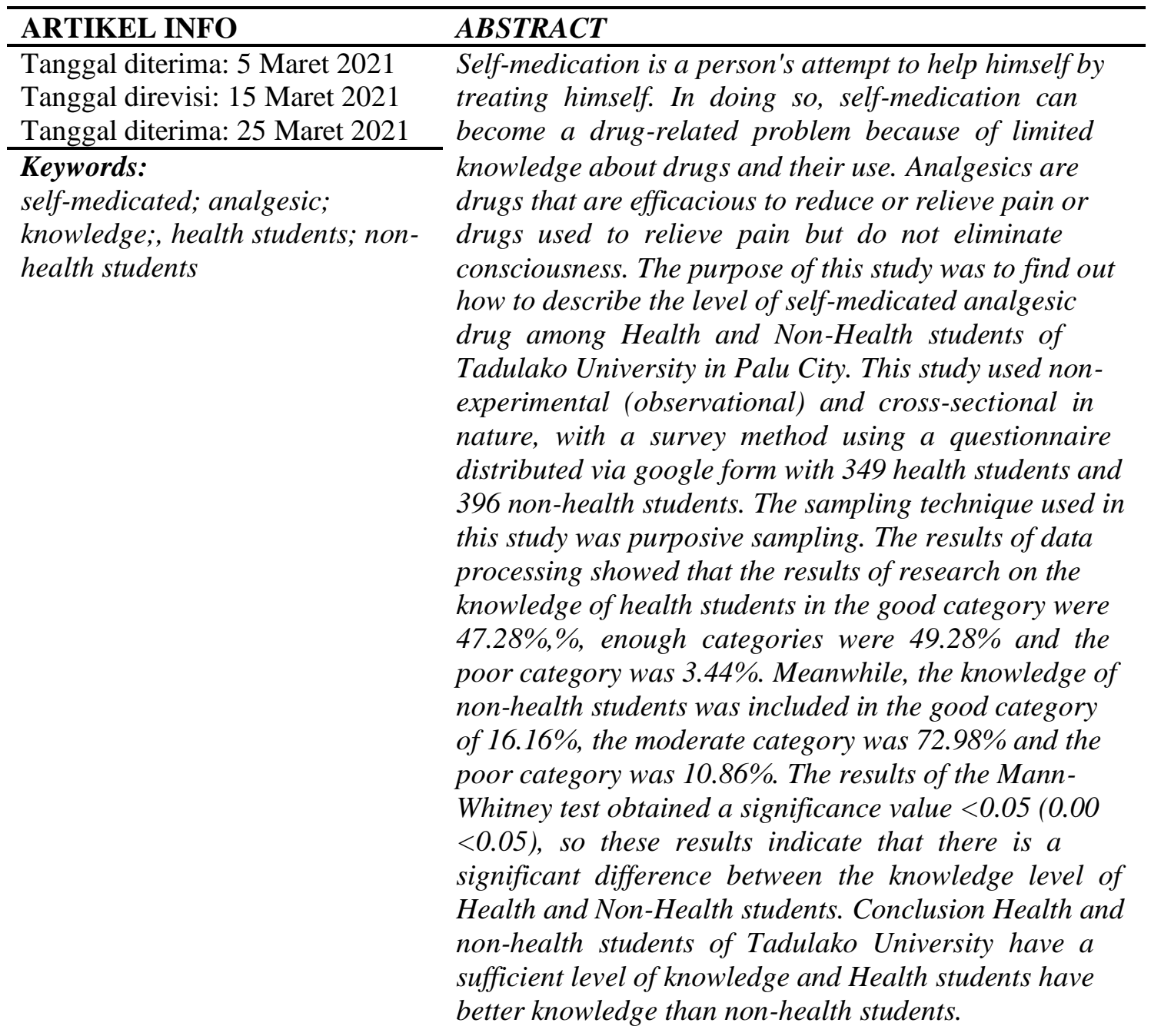

\section{ABSTRAK}

Swamedikasi merupakan usaha seseorang dalam menolong dirinya sendiri berupa mengobati dirinya sendiri. Dalam menjalankannya, swamedikasi bisa menjadi masalah terkait obat (Drug related problem) karena pengetahuan yang terbatas mengenai obat dan penggunaannya. Analgesik merupakan obat yang berkhasiat untuk mengurangi atau menghilangkan rasa nyeri atau obat-obat yang digunakan untuk menghilangkan rasa sakit tetapi tidak menghilangkan kesadaran. Tujuan dari penelitian ini adalah mengetahui 


\section{Kata Kunci:}

swamedikasi; pengetahuan; kesehatan; kesehatan

bagaimana gambaran tingkat pengetahuan swamedikasi obat analgesik pada mahasiswa Kesehatan dan Non Kesehatan Universitas Tadulako di Kota Palu. Penelitian ini menggunakan metode non eksperimental (observasional) dan bersifat cross sectional, dengan metode survei menggunakan kuesioner yang disebar melalui google form dengan jumlah mahasiswa kesehatan 349 responden dan mahasiswa Non kesehatan 396 responden. Teknik dalam pengambilan sampel yang digunakan pada penelitian ini yaitu purposive sampling. Hasil pengolahan data didapatkan hasil penelitian pengetahuan mahasiswa Kesehatan pada kategori baik sebesar 47,28 \%, \%, kategori cukup sebesar 49,28 \% dan kategori kurang 3,44\%. Sedangkan pengatahuan mahasiswa non Kesehatan masuk kedalam kategori baik sebesar $16,16 \%$, ketegori cukup sebanyak 72,98 \% dan kategori kurang sebanyak $10,86 \%$. Hasil uji mannwhitney diperoleh nilai signifikansi $<0,05(0,00<0,05)$ maka hasil tersebut menunjukkan terdapat perbedaan yang signifikan antara tingkat pengetahuan mahasiswa analgesik, Kesehatan dan Non Kesehatan. Kesimpulan mahasiswa mahasiswa kesehatan dan non kesehatan universitas tadulako mahasiswa non memiliki tingkat pengetahuan yang cukup dan mahasiswa Kesehatan memiliki pengetahuan yang lebih baik dibandingkan mahasiswa non Kesehatan.

Coresponden Author:

Email: riniaskaar@gmail.com Artikel dengan akses terbuka dibawah lisensi

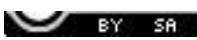

\section{Pendahuluan}

Kesehatan adalah hal yang penting bagi kehidupan manusia, Ketika seseorang mengalami sakit maka ia akan berupaya untuk mengembalikan kesehatannya. Hal yang sering dilakukan oleh seseorang agar Kembali sehat adalah berobat ke dokter atau mengobati diri sendiri yang biasa disebut dengan swamedikasi. Mengobati diri sendiri merupakan hal yang paling sering dilakukan seseorang sebelum memutuskan berobat ke dokter (Wolfe \& Horowitz, 2017).

Swamedikasi dapat menimbulkan efek samping yang tidak diinginkan apabila seseorang tidak mengetahui cara melakukan swamedikasi yang benar sesuai dengan gejala yang dialami. Swamedikasi hanya dilakukan untuk penyakit-penyakit ringan dan tidak untuk penyakit-penyakit serius. Penyakit yang biasanya bisa diobati dengan swamedikasi diantaranya adalah Alergi, anemia, asma, batuk, biang keringat, demam, dermatitis diare dan masih banyak lagi penyakit lainnya yang bisa di obati dengan swamedikasi (Nurochman \& Solikhah, 2015). Berdasarkan penelitian yang dilakukan oleh (Harahap, 2017) persentase swamedikasi terbesar yang dilakukan responden di Kota Panyabungan adalah nyeri yaitu sebesar $51,2 \%$, nyeri yang dialami responden berupa nyeri kepala, sakit gigi, pegal-pegal dan nyeri haid.

Analgesik merupakan obat yang memiliki khasiat dapat mengurangi atau menghilangkan rasa nyeri yaitu berupa obat- 
obat yang dapat menghilangkan rasa sakit tetapi tidak menghilangkan kesadaran. Obat ini sering digunakan oleh banyak orang dalam menghilangkan rasa sakit tanpa kita sadari kita sering mengkonsumsi obat yang memiliki komponen analgesik atau Pereda nyeri seperti sakit kepala dan sakit gigi (Mita \& Husni, 2017). Menggunakan obat analgesik yang tidak benar dan tidak sesuai dengan resep dokter dapat menyebabkan timbulnya efek samping yang tidak diinginkan dianataranya adalah efek samping seperti tukak lambung, mual, resiko perdarahan, telinga berdengung dan lain-lain. Sehingga penggunaan obat analgesik yang tepat dan sesuai dengan resep dokter sangat penting untuk menghindari resiko efek samping yang ada (Khalid et al., 2017).

Berdasarkan data dari Badan Pusat Statistik (BPS) (2019) tentang swamedikasi oleh penduduk Indonesia di peroleh data dari tahun 2017 masayarakat yang melakukan pengobatan sendiri adalah sebesar 69,43\%, pada tahun 2018 sebesar 70,74\%, pada tahun 2019 sebesar $71,46 \%$, untuk persentase pengobatan sendiri yang dilakukan oleh masyarakat Sulawesi Tengah pada tahun 2017 sebesar $77,97 \%$, pada tahun 2018 sebesar 73,93 $\%$ dan pada tahun 2019 sebesar 75,45\% (Badan Statistik Pusat, 2020).

Untuk meningkatkan kemampuan masyarakat dalam menolong dirinya sendiri guna mengatasi masalah kesehatan dirasa perlu ditunjang dengan sarana yang dapat meningkatkan swamedikasi secara tepat, amandanrasional, maka pemerintah menerbitkan Keputusan Menteri Kesehatan Nomor: 919/MENKES/PER/X/1993 pasal 2 tentang Obat Tanpa Resep, yang terdiri dari obat bebas, obat bebas terbatas, dan obat wajib apotek (OWA) yang dapat diberikan oleh Apoteker kepada pasien di apotek tanpa resep dokter. Tujuan utama diterbitkannya Keputusan Menteri Kesehatan saat itu adalah untuk swamedikasi, pasien dapat mengobati dirinya sendiri secara rasional dan ditunjang dengan adanya obat wajib apotek tersebut (yusrizal 2015).

Penelitian ini berfokus pada responden tingkat mahasiswa. Berdasarkan dengan penelitian yang telah dilakukan oleh (Aljaouni et al., 2015) pada mahasiswa di Universitas Taibah Madinah Saudi Arabia menunjukkan prevelensi swamedikasi dikalangan mahasiswa cukup tinggi yaitu sebesar 64,8\%. Mahasiswa adalah kelompok pelajar yang menempuh pendidikan tinggi dan memiliki pengetahuan yang lebih baik jika dibandingkan dengan masyarakat secara umum, sehingga pentingnya melihat pengetahuan swamedikasi obat analgesik pada mahasiswa agar dalam kehidupan bermasyarakat dapat memberikan informasi yang berdampak positif.

Dari survei pendahuluan yang dilakukan pada mahasiswa-mahasiswi Universitas Tadulako di Kota Palu, terdapat 35 dari 39 mahasiswa yang melakukan swamedikasi menggunakan obat analgesik sebagai penghilang rasa sakit. Berdasarkan data dari hasil survei pendahuluan tersebut ternyata angka penggunaan obat analgesik oleh mahasiswa-mahasiswi Universitas Taulako di Kota Palu relatif banyak sehingga peneliti menggunakan sampel mahasiswamahasiswi Universitas Tadulako sebagai reseponden dalam penelitian ini.

Berdasarkan penelitian yang telah dilakukan ditemukan hasil yang berbeda pada penelitian sebelumnya dimana tingkat pengetahuan mahasiswa-mahasiswi Kesehatan dan non Kesehatan dalam penelitian ini di dominasi kategori cukup sedangkan pada penelitian sebelumnya di dominasi kategori baik. Hal ini disebabkan karena perbedaan sampel pada tiap penelitian yang digunakan sehingga dapat menghasilkan tingkat pengetahuan yang berbeda pada tiap 
populasi penelitian. Hal-hal yang dapat mempengaruhi perbedaan pengetahuan tersebut di antaranya adalah Pendidikan, pekerjaan, pengalaman, Usia, Kebudayaan, Minat serta informasi yang di dapatkan oleh responden penelitian.

\section{Metode Penelitian}

Penelitian ini merupakan penelitian deskriptif non eksperimental dengan menggunakan desain penelitian cross sectional dengan menggunakan kuesioner dalam bentuk google form untuk mengetahui gambaran tingkat pengetahuan Swamedikasi Obat Analgesik pada Mahasiswa Kesehatan dan Non Kesehatan Universitas Tadulako di Kota Palu.

Penelitian ini dilakukan pada bulan Oktober 2020 bertempat di Universitas Tadulako Jl. Soekarno Hatta, KM. 9, Tondo, Mantikulore, Kota Palu, Sulawesi Tengah. Teknik pengambilan sampel purposive sampling yaitu semua mahasiswa yang memenuhi kriteria inklusi dan eksklusi.

Validitas merupakan indeks yang menyatakan suatu alat ukur dapat mengukur apa yang ingin kita ukur. Untuk mengetahui kuesioner yang kita susun apakah mampu mengukur apa yang ingin kita ukur, Pertanyaan-pertanyaan di ujikan kepada sekelompok responden sebagai responden uji coba. Responden yang digunakan adalah sebanyak 30 orang utuk uji validitas. Uji validitas dilakukan dengan menggunakan aplikasi SPSS 21 dengan ketentuan kuesioner dianggap layak apabila $r$ hitung lebih besar dari $r$ tabel. Reliabilitas merupakan indeks yang menyatakan kehandalan atau sejauh mana suatu alat pengukur dapat dipercaya. Uji reliabilitas menggunakan aplikasi SPSS dimana semua pertanyaan yang di nyatakan valid di uji reliabilitasnya, instrument dikatakan reliabel apabila nilai Cronbach's Alpha minimal 0,6.
Penelitian ini telah dinyatakan sesuai dengan prinsip-prinsip etika penelitian oleh Komite Etik Penelitian Fakultas Kedokteran Universitas Tadulako dengan dikeluarkannya Surat Pernyataan Komite Etik dengan nomor; 79/9/UN 28.1.30/KL/2020.

\section{Hasil dan Pembahasan}

\section{a. Uji Validitas}

Tabel 1

Uji Validitas

\begin{tabular}{cccc}
\hline Pertanyaan & $\begin{array}{c}\mathbf{r} \\
\text { hitung }\end{array}$ & $\begin{array}{c}\mathbf{r} \\
\text { tabel }\end{array}$ & $\begin{array}{c}\text { Keterang } \\
\text { an }\end{array}$ \\
\hline P1 & 0,610 & 0,361 & Valid \\
\hline P2 & 0,386 & 0,361 & Valid \\
\hline P3 & 0,510 & 0,361 & Valid \\
\hline P4 & 0,475 & 0,361 & Valid \\
\hline P5 & 0,676 & 0,361 & Valid \\
\hline P6 & 0,609 & 0,361 & Valid \\
\hline P7 & 0,452 & 0,361 & Valid \\
\hline P8 & 0,472 & 0,361 & Valid \\
\hline P9 & 0,392 & 0,361 & Valid \\
\hline P10 & 0,603 & 0,361 & Valid \\
\hline P11 & 0,502 & 0,361 & Valid \\
\hline P12 & 0,444 & 0,361 & Valid \\
\hline P13 & 0,478 & 0,361 & Valid \\
\hline P14 & 0,557 & 0,361 & Valid \\
\hline P15 & 0,458 & 0,361 & Valid \\
\hline P16 & 0,502 & 0,361 & Valid \\
\hline
\end{tabular}

Menurut (Erwanto et al., 2014) validitas adalah sejauh mana ketepatan dari suatu alat ukur yang ingin dipakai, uji validitas didapatkan dari hasil data yang berasal dari jawaban hasil kuesioner dengan memakai korelasi person product moment yaitu di dalam satu variabel terdapat korelasi antar item dengan skor total. Pengujian menggunakan software SPSS versi 21 dengan jumlah sampel $(n)=$ 30 responden sehingga didapatkan nilai $r$ tabel sebesar 0,361. Dari uji validitas yang telah dilakukan didapatkan hasil pertanyaan yang valid berjumlah 16 pertanyaan dari 30 pertanyaan dengan menggunakan 30 responden. 
b. Uji Reliabilitas

Tabel 2

Uji Reliabilitas

\begin{tabular}{cc}
\hline $\begin{array}{l}\text { Cronbach's } \\
\text { Alpha }\end{array}$ & N of Items \\
\hline 832 & 16 \\
\hline
\end{tabular}

Reliabilitas merupakan tingkat keterandalan, kepercayaan, konsistensi, atau kemantapan hasil suatu pengukuran (Indrawati \& Suratini, 2015). Dalam uji reliabilitas untuk mengetahui reliabilitas suatu instrument penelitian digunakan Rumus cronbach's alpha yaitu rumus matematis yang dapat digunakan untuk mengetahui reliabiltas suatu instrument yang diujikan. Uji reliabilitas menggunakan aplikasi SPSS versi 21 dimana semua pertanyaan yang di nyatakan valid di uji reliabilitasnya.

Dimana didapatkan hasil seluruh 16 pertanyaan dinyatakan reliabel dengan nilai Cronbach alpha sebesar 0,832 dimana menurut (Erwanto et al., 2014) instrument dinyatakan reliabel dengan nilai Cronbach's Alpha minimal 0,6.

c. Sampel

\section{Mahasiswa Kesehatan}

Tabel 3

\begin{tabular}{lcc}
\multicolumn{3}{c}{ Mahasiswa Kesehatan } \\
\hline $\begin{array}{c}\text { Karakteristik } \\
\text { Responden }\end{array}$ & $\begin{array}{c}\text { Jumlah } \\
\text { Respon } \\
\text { den } \\
(\mathbf{n = 3 4 9 )}\end{array}$ & $\begin{array}{c}\text { Persentas } \\
\mathbf{e}(\mathbf{\%})\end{array}$ \\
\hline Usia & 115 & 32,95 \\
\hline 17-19 Tahun & 230 & 65,90 \\
\hline 20-22 Tahun & 4 & 1,14 \\
\hline 23-25 Tahun & 349 & 100 \\
\hline Total & & \\
\hline Jenis Kelamin & 57 & 16,33 \\
\hline Laki-laki & 292 & 83,67 \\
\hline Perempuan & 349 & 100 \\
\hline Total & 11 & 3,15 \\
\hline Angkatan & 70 & 20,06 \\
\hline 2016 & 164 & 46,99 \\
\hline 2017 & 104 & 29,80 \\
\hline 2018 & $\mathbf{3 4 9}$ & $\mathbf{1 0 0}$ \\
\hline 2019 &
\end{tabular}

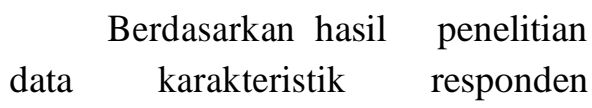

mahasiswa kesehatan yang paling banyak mengisi kuesioner yaitu usia

20-22 tahun sebanyak 230 responden dengan persentase $(65,90$ $\%)$, hal ini dikarenakan kebanyakan responden berasal dari Angkatan 2017 sampai 2019 dengan rentang usia rata-rata dimulai dari usia 17 tahun-22 tahun. Jenis kelamin yang paling banyak mengisi adalah jenis kelamin perempuan sebanyak 292 responden dengan persentase sebesar 83,67 \% dikarenakan mahasiswa Kesehatan kebenyakan adalah perempuan. Dan angkatan terbanyak berasaldari tahun 2018 sebanyak 164 responden dengan persentase sebesar $46,99 \%$ karena peneliti mendapatkan banyak kontak dan respon yang baik dari Angkatan 2018 dibandingkan Angkatan yang lain.

2. Mahasiswa Non Kesehatan

Tabel 4

Mahasiswa Non Kesehatan

\begin{tabular}{lcc}
\hline $\begin{array}{c}\text { Karakteristik } \\
\text { Responden }\end{array}$ & $\begin{array}{c}\text { Jumlah } \\
\text { Responden } \\
(\mathbf{n = 3 9 6 )}\end{array}$ & $\begin{array}{c}\text { Persentas } \\
\mathbf{e}(\boldsymbol{\%})\end{array}$ \\
\hline Usia & 40 & 10,10 \\
\hline 17-19 Tahun & 326 & 82,32 \\
\hline 20-22 Tahun & 30 & 7,5 \\
\hline 23-25 Tahun & 396 & 100 \\
\hline Total & & \\
\hline Jenis Kelamin & 202 & 51,01 \\
\hline Laki-laki & 194 & 48,99 \\
\hline Perempuan & 396 & 100 \\
\hline Total & & 8,84 \\
\hline Angkatan & 35 & 63,38 \\
\hline 2016 & 251 & 17,17 \\
\hline 2017 & 68 & 10,61 \\
\hline 2018 & 42 & $\mathbf{1 0 0}$ \\
\hline 2019 & $\mathbf{3 9 6}$ &
\end{tabular}

Berdasarkan hasil penelitian data karakteristik responden mahasiswa non kesehatan yang paling banyak mengisi kuesioner yaitu usia 20-22 tahun sebanyak 326 responden dengan 
persentase $(82,32)$, hal ini dikarenakan kebanyakan responden berasal dari Angkatan 2017 sampai 2019 dengan rentang usia rata-rata dimulai dari usia

17 tahun-22 tahun. Jenis kelamin yang paling banyak mengisi adalah jenis

kelamin laki-laki sebanyak 202 responden dengan persentase sebesar $51,01 \%$ karena jumlah jenis kelamin laki-laki cukup banyak dan ada diseluruh program studi non kesehatan dan responden yang mengisi kuesioner kebanyakan berjenis kelamin laki-laki. dan Angkatan terbanyak berasal dari tahun 2017 sebanyak 251 responden dengan persentase sebesar 63,38 \% karena peneliti mendapatkan banyak kontak dan respon yang baik dari Angkatan 2017 dibandingkan Angkatan yang lain.

\section{d. Perbandingan Tingkat Pengetahuan berdasarkan Hasil Jawaban Kuesioner}

Tingkat Pengetahuan memiliki beberapa sub variabel. Sub vaariabel dalam penelitian ini yang diantaranya ada yang mengacu pada (DepKes, 2007) sub variabel pada penelitian ini yaitu Pengetahuan tentang golongan obat, Pengetahuan tentang pemilihan obat sesuai gejala penyakit, Pengetahuan tentang cara penggunaan obat yang tepat dalam swamedikasi, pengetahuan tentang efek samping obat, pengetahuan tentang keamanan obat analgesik, Pengetahuan tentang cara penyimpanan obat analgesik, pengetahuan tentang interaksi obat dengan makanan dan pengetahuan tentang ciri-ciri obat yang tidak boleh dikonsumsi.

1. Pengetahuan tentang golongan obat analgesik

Sub variabel pengetahuan tentang golongan obat analgesik pada soal pertanyaan nomor 1
"Parasetamol termasuk dalam golongan obat Analgesik" jawaban yang tepat dari pertanyaan tersebut adalah "Benar" jawaban yang benar adalah pilihan "benar" karena parasetamol merupakan golongan obat analgesik hal ini sesuai yang tedapat didalam jurnal (Fuadi \&

Redjeki, 2016) Parasetamol merupakan obat yang mempunyai efek analgesik dan bersifat sentral dan juga memiliki mekanisme kerja penghambatan produksi prostaglandin dengan menghambat aktivitas enzim siklooksigenase-2 yang sama seperti NSAID. pada pertanyaan nomor 2 "Semua obat

sakit kepala harus dibeli menggunakan resep" jawaban yang tepat dari pertanyaan tersebut adalah "salah" karena tidak semua obat

sakit kepala harus dibeli menggunakan resep hal ini sesuai dengan literature (DepKes, 2007)

yang menyatakan bahwa parasatemol merupakan obat yang boleh digunakan secara swamedikasi untuk menghilangkan nyeri termasuk nyeri kepala hal ini sesuai dengan penelitian yang dilakukan oleh (Tarazi et al., 2016) yang menyatakan bahwa parasetamol merupakan obat golongan analgesik yang paling banyak digunakan dalam swamedikasi, contoh obat sakit kepala yang mengandung parasetamol adalah Paramex dan Bodrex yang dapat dibeli di apotek tanpa menggunakan resep dokter. Pada pertanyaan nomor 3 "Bodrex merupkan obat yang mengandung parasetamol" jawaban yang tepat dari pertanyaan tersebut adalah pilihan "benar". Bodrex adalah nama dagang dari obat yang mengandung 
parasetamol (Oktaviana et al., 2019).

Dari hasil rata-rata pada sub variabel ini di dapatkan hasil bahwa mahasiswa Kesehatan memiliki kategori pengatahuan "baik" yaitu sebesar $82,43 \%$ sedangkan mahasiswa non Kesehatan memiliki kategori pengetahuan "cukup" yaitu sebesar $71,89 \%$.

2. Pengetahuan tentang pemilihan obat sesuai gejala penyakit

Sub variabel pengetahuan tentang pemilihan obat sesuai gejala penyakit pada pertanyaan nomor 4

"Amoxsan dapat digunakan untuk sakit kepala" jawaban yang tepat pada pertanyaan ini adalah pilihan "salah". Amoxsan tidak dapat digunakan untuk sakit kepala karena amoxsan merupakan obat Antibiotik yang mengandung Amoxicillin dan tidak diindikasikan untuk nyeri kapala. Hal ini sesuai dengan literatur (Sofyani et al., 2018) yaitu Amoxicillin adalah antibiotik yang memiliki mekanisme kerja sebagai antibakteri yang disebakan oleh

mikroorganisme yang rentan. Antibiotik ini merupakan antibiotik turunan penicillin yang memiliki cincin $\beta$-lactam. Berdasarkan hasil rata-rata jawaban responden pada sub variabel ini didapatkan hasil bahwa mahasiswa Kesehatan dan non Kesehatan memiliki kategori pengetahuan "kurang" yaitu sebesar $54,73 \%$ untuk mahasiswa Kesehatan dan 53,03 \% untuk mahasiswa non Kesehatan.

3. Pengetahuantentang cara penggunaan obat yang tepat dalam swamedikasi

Sub variabel pengetahuan tentang cara penggunaan obat yang tepat dalam swamedikasi untuk untuk pertanyaan nomor 5 "Obat sakit kepala tidak harus diminum sesuai dengan aturan yang ada dibungkus obat", jawaban yang tepat dari pertanyaan ini adalah pilihan "salah". Obat sakit kepala harus diminum sesuai dengan aturan yang ada dibungkus obat, dikarenakan aturan pakai dan dosis yang tepat terdapat pada kemasan obat sebagai petunjuk bagi masyarakat tentang cara penggunaan serta aturan pakai yang benar yang sesuai dengan Pedoman penggunaan obat bebas dan bebas terbatas, dimana agar penggunaan obat tetap aman maka sebelum menggunakannya, terlebih dahulu harus membaca sifat dan aturan pakai yang tepat yang tercantum pada etiket, brosur maupun kemasan obat. (DepKes, 2007).

Untuk pertanyaan nomor 6 "Jika pagi lupa minum obat asam mefenamat maka siang boleh menggandakan dosis obat" jawaban yang tepat pada pertanyaan ini adalah "salah". Tidak boleh menggandakan dosis apabila terlupa di pagi hari dan menggandakan dosisnya di siang hari karena hal

tersebut dapat menyebabkan kelebihan dosis obat dimana berdasarkan (Tsamakis et al., 2020) bahwa dosis obat asam mefenamat pada awal pengobatan adalah 500 mg sekali minum dan selanjutnya $250 \mathrm{mg}$ setiap 6 jam bila perlu biasanya tidak melebihi 7 hari. Menurut (DepKes, 2007) Dosis yang terlupa harus diminum segera setelah kita mengingatnya, tetapi apabila sudah mendekati waktu dosis obat selanjutnya, maka dosis yang terlupa tidak perlu di konsumsi dan menunggu ke jadwal minum selanjutnya sesuai dengan aturan 
minum obat. Pada pertanyaan nomor 7 "Ponstan adalah obat antinyeri yang tidak boleh digerus sebelum diminum" jawaban yang tepat dari pertanyaan tersebut adalah pilihan "benar". Karena ponstan merupakan obat analgesik yang mengandung asam mefenamat yang tidak boleh digerus sebelum diminum karena merupakan obat tablet salut selaput yang bertujuan untuk melindungi bahan kimia didalam obat agar berhasil sampai diusus dan tidak hancur saat melalui asam lambung sesuai dengan literatur (Rahmawati

\& Fajar, 2017) yang menyatakan bahwa tablet salut selaput adalah tablet yang dilapisi oleh selaput tipis polimer yang dapat larut atau tidak dapat larut dalam air. Selaput ini akanhancurdalamsaluran

gastrointestinal. Tujuan dari penggunaan salut selaput adalah untuk mencegah atau mengurangi terjadinya efek samping dari obat AINS, termasuk asam mefenamat yang dapat mengiritasi lambung. Sub variabel ini didapatkan hasil rata-rata mahasisw Kesehatan dan non kesehatan memiliki kategori pengetahuan "cukup" yaitu sebesar

$75,83 \%$ untuk mahasiswa Kesehatan dan 72,30 \% untuk mahasiswa non Kesehatan.

4. Pengetahuan tentang efek samping obat analgesik

Sub variabel pengetahuan tentang efek samping obat analgesik padapertanyaannomor8 "menggandakan dosis obat antinyeri lebih dari yang ditentukan bias menyebabkan penyakit ginjal" pilihan yang tepat pada pertanyaan tersebutadalah"benar".

Menggunakan dosis obat lebih dari dosis yang telah ditentukan dapat menyebabkan penyakit ginjal sesuai dengan literatur (Hapsari \& Nugroho, 2016) yang menyatakan bahwa penggunaan obat pada dosis besar, dapat memberikan efek toksik pada ginjal dan beberapa organ lainnya. Dan berdasarkan literatur (Supadmi \& Hakim, 2012) bahwa terdapat bukti epidemiologi menyatakan bahwa adanya kaitan antara penggunaan analgetik dan anti inflamasi non steroid yang bisa menyebabkan kerusakan ginjal dan nefropati akibat penggunaan yang berlebihan. Hal ini juga sejalan dengan penelitian yang dilakukan oleh (Supadmi \& Hakim, 2012) didapatkan hasil bahwa obat anti inflamasi non steroid berkaitan dengan kejadian gagal ginjal kronik diantaranya terdapat asam mefenamat. kejadian gagal ginjal kronik. Sedangkan pada pertanyaan nomor 9 "menggunakan obat asam mefenamat secara terus menerus

dapat menyebabkan gangguan saluran cerna" pilihan yang tepat pada pertanyaan ini adalah "benar". Hal ini berdasarkan literatur (Lovell \& Ernst, 2017) yang menyatakan bahwa penggunaan NSAID dapat memberikan efek samping dan komplikasi seperti gangguan fungsi ginjal, edema, hipertensi, dan perdarahan di gastrointestinal dan pada penelitian sebelumnya terlaporkan adanya efek terhadap jantung dan ginjal (Moore et al., 2015). Dan pada pertanyaan nomor 10 "Parasetamol adalah kandungan obat paramex yang dapat menyebabkan ngantuk" jawaban yang tepat pada pertanyaan tersebut adalah "salah". Parasetamol 
bukanlah kandungan obat paramex yang menyebabkan kantuk, melainkan paramex mimiliki kandungan Dexchlorpheniramine Maleat yang bisa memberikan efek kantuk bagi orang yang mengkinsumsinya. Antihistamin generasi pertama telah dikaitkan dengan efek samping yaitu sedasi, sedangkan pada antihistamin generasi kedua memiliki efek samping sedasi yang lebih kecil dibandingkan generasi pertama, sehingga antihistamin generasi kedua lebih banyak disukai (Poluzzi et al., 2015) pada sub variabel ini didapatkan hasil rata-rata responden mahasiswa Kesehatan dan non

kesehatan memiliki kategori pengetahuan "cukup" yaitu sebesar

68,67 \% untuk mahasiswa

Kesehatan dan 61,87 untuk mahasiswa non Kesehatan.

5. Pengetahuan tentang keamanan obat analgesik

Sub variabel pengetahuan tentang keamanan obat analgesik padapertanyaannomor11

"Parasetamol merupakan obat antinyeri yang aman untuk ibu hamil". Pilihan yang tepat pada jawaban diatas adalah "benar".

Berdasarkan literatur dikatakan bahwa parasetamol adalah obat yang aman digunakan pada ibu hamil karena merupakan obat kategori B yang artinya tidak memiliki resiko sama sekali pada sejumlah kasus, sehingga parasetamol menjadi obat aman untuk digunaka pada semua tahap kehamilan untuk menghilangkan rasa sakit pada ibu hamil. Parasetamol aman digunakan dalam jangka waktu pendek dan sesuai dengan dosis terapeutik (Dewi, 2020). Dan pada pertanyaan nomor 12 "parasetamol adalah obat antinyeri yang aman digunakan penderita asam lambung" jawaban yang tepat pada pertanyaan ini

adalah "benar". Berdasarkan

literatur dikatakan bahwa parasetamol memiliki kemampuan

dalam menghambat enzyme cyclooxygenase-1 (COX-1) yang lebih kecil dibandingkan NSAID. COX-1 berfungsi untuk proteksi gastrointestinal, fungsi trombosit dan ginjal. Sehingga penghambatan pada COX-1 yang lebih kecil menjadikan parasetamol lebih aman (Fuadi \& Redjeki, 2016). Sehingga parasetamol adalah obat analgetik yang lebih aman digunakan

penderita asam lambung dibandingkan dengan NSAID. Pada sub variabel ini didapatkan hasil rata-rata mahasiswa Kesehatan yang memiliki kategori pengetahuan "Cukup" yaitu sebesar 75,79 \%

sedangkan mahasiswa non Kesehatan memiliki kategori pengetahuan "kurang" yaitu sebesar $55,05 \%$.

6. Pengetahuan tentang cara penyimpanan obat Analgesik

Sub variabel pengetahuan tentang cara penyimpanan obat analgesik pada soal nomor 13 "Menyimpan obat sakit kepala di dalam kulkas dapat mempengaruhi kualitas obat" jawaban yang benar adalah pilihan "benar". berdasarkan literatur bahwa salah faktor yang dapat mempengaruhi stabilitas

suatu obat adalah cara penyimpanan. Salah satu faktor yang mempengaruhi kondisi penyimpanan adalah suhu, suhu yang sesuai dapat mencegah

terjadinya kerusakan yang mempengarhi kualitas dan keamanan suatu produk farmasi dan tidak mengakibatkan dampak yang 
merugikan terhadap obat baik itu secera langsung maupun tidak langsung. (BPOM, 2018). Contoh cara menyimpan obat di rumah yaitu seperti tidak menyimpan tablet atau kapsul di tempat panas atau yang terkena sinar matahari dan tidak menyimpan obat pada tempat yang lembab (DepKes, 2007). Dimana

kulkas merupakan tempat penyimpanan yang memiliki tingkat kelembapan yang tinggi. Dan pada pertanyaan nomor 14 "Obat sakit kepala harus disimpan ditempat yang memiliki tingkat kelembapan yang rendah" jawaban yang tepat dari pertanyaan tersebut adalah pilihan "benar". Berdasarkan literatur dikatakan bahwa untuk menjaga obat dari pengaruh kelembaban, suhu dan sinar matahari obat harus disimpan dengan baik. (Goleman et al., 2019). Suhu dan kelembapan relatif yang tinggi

adalah faktor yang paling berpengaruh terhadap degradasi suatu obat (Goleman et al., 2019). Pada sub variabel ini didapatkan hasil rata-rata mahasiswa Kesehatan memiliki kategori pengetahuan "baik" yaitu sebesar 76,79\%

sedangkan mahasiswa non Kesehatan memiliki kategori pengetahuan "cukup" yaitu sebesar $71,46 \%$.

7. Pengetahuan tentang interaksi obat dengan makanan

Sub variabel pengetahuan tentang interaksi obat dengan makanan pada pertanyaan nomor 15 "Mengonsumsi antinyeri bersama dengan teh dapat menyebabkan interaksi pada obat" jawaban yang benar adalah pilihan "benar".

Berdasarkan literatur Menurut Teh memiliki kandungan zat tannin dimana zat ini memiliki aktivatas yang dapat menghambat absorbsi dari suatu obat, karena tannin sangat mudah berinteraksi (Khuluq, 2020). Sehingga dapat disimpulkan bahwa mahasiswa Kesehatan memiliki pengetahuan kategori "baik" sebesar $81,66 \%$ sedangkan mahasiswa non Kesehatan mimiliki pengetahuan "cukup" sebesar 65,91\%.

8. Pengetahuan tentang ciri obat yang tidak boleh dikonsumsi

Sub variabel tentang ciri obat yang tidak boleh dikonsumsi pada pertanyaan nomor 16 "Adanya perubahan warna, bau dan rasa pada obat anti nyeri menandakan obat tidak boleh lagi diminum. Jawaban yang tepat dari pertanyaan tersebut adalah pilihan "benar". Berdasarkan literatur menyatakan stabilitas sediaan farmasi adalah salah satu syarat yang amat penting agar hasil produksi yang didaptkan baik. Ketidakstabilan suatu obat dapat menyebabkan penurunan bahkan hilangkan khasiat dari suatu produk obat. obat dapat berubah dan mberikan efek toksik dan menyebabkan terjadinya perubahan penampilan suatu produk obat yang berupa perubahan warna, bau, rasa dan konsistensi (Pratiwi et al., 2018). Perubahan warna bau dan rasa pada obat menandakan obat tidak dapat dikonsumsi lagi karena menandakan obat sudah tidak memiliki stabilitas yang baik. Berdasarkan hasil rata-rata jawaban responden pada sub variabel ini berdasarkan hasil rata-rata jawaban responden dapat disimpulkan bahwa pengetahuan mahasiswa Kesehatan dan non kesehatan masuk kategori 
baik sebesar 95,99 \% untuk mahasiswa Kesehatan dan 90,91\% untuk mahasiswa non Kesehatan.

\section{e. Hasil Tingkat Pengetahuan Responden \\ Tabel 5 \\ Hasil Tingkat Pengetahuan Responden}

\begin{tabular}{lcccc}
\hline Responden & \multicolumn{3}{c}{ Pengetahuan } & Total \\
\hline & Kurang & Cukup & Baik & \\
\hline Mahasiswa & 12 & 172 & 165 & 349 \\
Kesehatan & $3.44 \%$ & $249.28 \%$ & $47,28 \%$ & $100 \%$ \\
\hline Mahasiswa & 43 & 289 & 64 & 396 \\
non Kesehatan & $10.86 \%$ & $72.98 \%$ & 16.16 & $100 \%$ \\
\hline
\end{tabular}

Hasil tabel 5 dapat disimpulkan bahwa mahasiswa Kesehatan yang memiliki

Pengetahuan kurang sebanyak 12 responden dengan persentase sebesar 3,44 \%,yang memiliki pengetahuan cukup sebanyak 172 responden, dengan persentase 49,28

$\%$ dan yang memiliki pengetahuan baik sebanyak 165 responden dengan persentase sebesar 47,28\%.

Hasil tersebut tidak sejalan dengan penelitian yang dilakukan oleh (Lestari Et Al., 2020) pada mahasiswa Kesehatan dan non Kesehatan Universitas Ngudi Waluyo tentang swamedikasi analgesik dimana hasil yang didapatkan tingkat pengetahuan mahasiswa fakultas Kesehatan pada kategori kurang sebesar 13,4\%, kategori cukup sebesar 35,4 \% dan kategori baik sebesar 51,2\% dimana kategori pengetahuan mahasiswa fakultas Kesehatan didominasi pada kategori baik. Pada mahasiswa non Kesehatan yang memiliki pengetahuan kurang sebanyak 43 responden dengan persentase sebesar $10,86 \%$, yang memiliki pengetahuan cukup 289 dengan persentase sebesar $72,98 \%$ dan yang memiliki pengetahuan baik sebanyak 64 orang dengan persentase sebesar $16,16 \%$. Hal ini juga tidak sejalan dengan hasil penelitian tersebut dimana tingkat pengetahuan mahasiswa fakultas non Kesehatan yang memiliki kategori kurang sebesar 12,2\%, yang memiliki kategori cukup sebesar $31,7 \%$ dan yang memiliki kategori baik sebesar 56,1 \% sehingga pengetahuan mahasiswa non Kesehatan didominasi pada kategori baik.

\section{f. Perbandingan Tingkat Pengetahuan Responden berdasarkan hasil uji Mann Whitney U}

Tabel 6

Perbandingan Tingkat

Pengetahuan Responden

berdasarkan hasil uji Mann

Whitney U

\begin{tabular}{lc}
\hline & Pengetahuan \\
\hline $\begin{array}{l}\text { Mann- } \\
\text { Whitney U }\end{array}$ & 40972.000 \\
\hline Wilcoxon W & 119578.000 \\
\hline Z & -9.718 \\
\hline $\begin{array}{l}\text { Asymp. Sig } \\
\text { (2-tailed) }\end{array}$ & 0.000 \\
\hline
\end{tabular}

Hasil Tabel 6 diperoleh hasil nilai probabilitas Asymp. Sig (2Tailed) $0.000<0,05$, maka Ho ditolak yang berarti ada perbedaan tingkat pengetahuan yang signifikan antara pengetahuan mahasiswa Kesehatan dan non Kesehatan Universitas Tadulako di Kota Palu tentang swamedikasi analgesik. Diketahui meskipun tingkat pengetahuan mahasiswa Kesehatan dan non Kesehatan di dominasi pada kategori cukup, tetapi tingkat pengetahuan mahasiswa Kesehatan lebih baik dibandingkan mahasiswa 
non Kesehatan hal berdasarkan data

persentase dimana terdapat

perbedaan jumlah persentase yang

signifikan pada tiap kategori

penegetahuan dimana data menunjukkan bahwa mahasiswa Kesehatan memiliki persentase ketegori pada pengetahuan baik yang lebih tinggi dibandingkan

mahasiswa non kesehatan, sedangkan mahasiswa non Kesehatan memiliki persentase yang

lebih tinggi pada kategori pengetahuan cukup dan kurang.

\section{Kesimpulan}

Pertama Tingkat pengetahuan mahasiswa Kesehatan yaitu yang memiliki tingkat pengetahuan kurang sebanyak 3,44\%, yang memiliki pengetahuan cukup sebanyak $49,28 \%$ dan yang memiliki pengetahuan baik sebanyak $47,28 \%$. Sehingga pengetahuan mahasiswa kesehatan didiominasi kategori cukup.

Kedua Tingkat Pengetahuan mahasiswa Non Kesehatan yaitu yang memiliki tingkat pengetahuan kurang sebanyak 10,86 \% \%, yang memiliki pengetahuan cukup sebanyak $72,98 \%$ dan yang memiliki pengetahuan baik sebanyak $16,16 \%$. Sehingga pengetahuan mahasiswa non kesehatan di dominasi kategori cukup.

Ketiga Perbandingan tingkat pengetahuan mahasiswa Kesehatan dan non Kesehatan yaitu dimana terdapat perbandingan yang signifikan dan dilihat dari nilai $\mathrm{p}<0,05$ atau $\mathrm{p}=0,000$.

\section{BIBLIOGRAFI}

Aljaouni, M. E., Hafiz, A. A., Alalawi, H. H., Alahmadi, G. M., \& Alkhawaja, I. (2015). Self Medication Practice Among Medical And Non Medical Students At Taibah University, Madinah, Saudi
Arabia. International Journal of Academic Scientific Research, 3(4), 22726446.

Badan Pusat Statistik (2020). Persentase Penduduk yang mengobati Sendiri Selama Sebulan Terakhir, 2015-2020.

Diakses dari :

https://www.bps.go.id/indicator/30/1974

/1/persentase-penduduk-yangmengobati-sendiri-selama-sebulanterakhir.html [Diakses tanggal 3 Oktober 2020].

BPOM. (2018). Peraturan Kepala Badan Pengawas Obat Dan Makanan Republik Indonesia Nomor 34/2018 Tentang Cara Pembuatan Obat Yang Baik. Bpom, 53, 1689-1699.

Depkes RI. (2007). Pedoman Penggunaan Obat Bebas Dan Bebas Terbatas. Pedoman Penggunaan Obat Bebas Dan Bebas Terbatas, 36.

Fitrianstah, A., \& Rahmawati, R. (2013). Analisis Kuantitatif Kadar Zat Asam Mefenamat Di Apotek Unisia Polifarma UII (Pp. 1-12).

Fuadi, I., \& Redjeki, I. S. (2016). Perbandingan Efek Pemberian Analgesia Pre-Emtif Parecoxib Dengan

Parasetamol Terhadap Nyeri Pascaoperasi Radikal Mastektomi Menggunakan Numeric Rating Scale. Jurnal Anestesi Perioperatif, 4(2), 111116.

Goleman Et Al., 2019. (2019). 済無 No Title No Title. Journal of Chemical Information And Modeling, 53(9), 16891699.

Hapsari, I., \& Nugroho, T. (2016). Pengaruh Pemberian Analgesik Kombinasi Parasetamol Dan Tramadol Terhadap Kadar Ureum Serum Tikus Wistar. Jurnal Kedokteran Diponegoro, 5(4), 1054-1063. 
Harahap, N. A., Khairunnisa, K., \& Tanuwijaya, J. (2017). Patient Knowledge And Rationality Of SelfMedication In Three Pharmacies Of Panyabungan City, Indonesia. Jurnal Sains Farmasi \& Klinis, 3(2), 186.

Idacahyati, K., Nofianti, T., Aswa, G. A., \& Nurfatwa, M. (2020). Hubungan Tingkat Kejadian Efek Samping Antiinflamasi Non Steroid Dengan Usia Dan Jenis Kelamin. Jurnal Farmasi Dan Ilmu Kefarmasian Indonesia, 6(2), 56.

Indrawati. (2015). Metode Penelitian Manajemen Dan Bisnis Konvergensi Teknologi Komunikasi Dan Informasi. Aditama.

Khuluq, H., \& Zukhruf, N. (2019). Gambaran Tingkat Pengetahuan Terhadap Penggunaan Obat Analgetik Pada

Masyarakat Desa Tanjungsari, Petanahan, Kabupaten Kebumen. Jurnal Ilmiah Kesehatan Keperawatan, 15(2), 50-54.

Kumala Dewi, A. A. R. M. F., Yuliyani, A. S., Dianita, B. R., Trimanda, D. A. W., Erliana, F. T., Kurniawan, H., Muzaffar, M. Z. R., Rachmafebri, R., Sakinah, S., Pebriastika, V. A., \& Nita, Y. (2020). Pengetahuan Dan Penggunaan Obat Analgesik Dan Antipiretik Pada Ibu Hamil. Jurnal Farmasi Komunitas, 7(1), 8.

Lestari, V. A. (2020). Tingkat Pengetahuan, Sikap Dan Perilaku Mahasiswa Kesehatan Dan Non Kesehatan Universitas Ngudi Waluyo Ungaran Terhadap Swamedikasi Analgesik. Skripsi. Universitas Ngudi Waluyo.

Lovell, A. R., \& Ernst, M. E. (2017). DrugInduced Hypertension: Focus On Mechanisms And Management. Current Hypertension Reports, 19(5).

Majid, Y. A., Lestari, W., Kunci, K., \& Sendiri, P. (2017). HUBUNGAN Pengetahuan Dan Sikap Dalam Penggunaan Obat Analgetik Bebas
Untuk Pengobatan Sendiri Pada Mahasiswa Psik Angkatan 2015 Stikes Muhammadiyah Palembang. 5, 303314.

Mita, R. S., \& Husni, P. (2017). Pemberian Pemahaman Mengenai Penggunaan Obat Analgesik Secara Rasional Pada Masyarakat. Aplikasi Ipteks Untuk Masyarakat, 6(3), 193-194.

Moore, N., Pollack, C., \& Butkerait, P. (2015). Adverse Drug Reactions And Drug - Drug Interactions With OverThe-Counter Nsaids. 1061-1075.

Nurochman, C., Waskita, M., Pranata, A., \& Muhammad, N. (2015). Aplikasi Swamedikasi Berbasis Android. 0274, 106-115.

Oktaviana, E., Hidayati, I. R., \& Pristianty, L. (2019). Pengaruh Pengetahuan Terhadap

Penggunaan Obat Parasetamol Yang Rasional Dalam Swamedikasi (Studi Pada Ibu Rumah Tangga Di Desa

Sumberpoh Kecamatan Maron Kabupaten Probolinggo). Jurnal Farmasi Dan Ilmu Kefarmasian Indonesia, 4(2), 44.

Poluzzi, E., Raschi, E., Godman, B., Koci, A., Moretti, U., Kalaba, M., Wettermark, B., Sturkenboom, M., \& De Ponti, F. (2015). Pro-Arrhythmic Potential of Oral Antihistamines (H1): Combining Adverse Event Reports With Drug Utilization Data Across Europe. Plos ONE, 1O(3), 1-14.

Pratiwi, L., Fudholi, A., Martien, R., \& Pramono, S. (2018). Uji Stabilitas Fisik Dan Kimia Sediaan SNEDDS (SelfNanoemulsifying Drug Delivery System) Dan Nanoemulsi Fraksi Etil Asetat Kulit Manggis (Garcinia Mangostana L.) Physical And Chemical Stability Test Of SNEDDS (SelfNanoemulsifying Drug Delivery System) A. Traditional Medicine Journal, 23(2), 84-90.

Sofyani, C. M., Taofik, R., \& Chaerunnisa, A. 
Y. (2018). Validasi Metode Analisis Kromatografi Cair Kinerja Tinggi Untuk PenetapanKadarUjiDisolusi

Terbanding Tablet Amoksisilin.

Farmaka, 16, 324-330.

Sugiyono. (2014). Metode Penelitian Pendidikan Pendekatan Kuantitatif, Kualitatif, Dan R\&D. Alfabeta.

Supadmi, W., \& Hakim, L. (2012). Kaitan Penggunaan Obat Analgetik Dan Anti Inflamasi Non Steroid Dengan Kejadian Gagal Ginjal Kronik Pada Pasien Hemodialisis Di Rsu Pku Muhammadyah Yogyakarta. Jurnal Ilmiah Farmasi, 9(2).

Tarazi, S., Almaaytah, A., Laham, N. Al, Ayesh, B., \& Arafat, H. (2016). Prevalence Of Self-Medication Practice Among Al-Azhar Medical Laboratory University Students Gaza Strip Palestine Department Of Laboratory Medicine, Faculty Of Applied Medical Department Of Pharmaceutical Technology , Faculty Of Pharmacy ,. Paripex - Indian Journal Of Research, 5(October), 231-234.

Wolfe, D. T., Hermanson, D. R., Ii, B. A. B., Diri, A. K., Diri, P. K., Chotimah, C., Rohayati, S., Мурашко M.A., , نلإياك ث نيسحملاغ, كوداس Akademik, K., Reza Yuka Satria Pratama，加藤真也,小林千 秋中西優子, Rusno, Ips, B., Kelas, S., Sdn, I. V, Tahun, T., ... Noviyani, D. I. (2017). No Title هصلاخ يكثزيناور. Educational Psychology Journal, 2(2), 65-72.

yusrizal. 2015. "Gambaran Penggunaan Obat Dalam Upaya Swamedikasi Pada Pengunjung Apotek Pandan Kecamatan Jati Agung Kabupaten Lampung Selatan Tahun 2014 The Picture of Medication Use In An Effort Swamedikasi On Visitors Pharmacies Pandan Districts Jati Agung Regency Sout." Gambaran
Penggunaan Obat Dalam Upaya Swamedikasi Pada Pengunjung Apotek Pandan Kecamatan Jati Agung Kabupaten Lampung Selatan Tahun 2014 4(1): 446-49. 